\title{
An Antarctic Extreme Halophile and Its Polyextremophilic Enzyme: Effects of Perchlorate Salts
}

\author{
Victoria J. Laye and Shiladitya DasSarma
}

\begin{abstract}
Effects of perchlorate salts prevalent on the surface of Mars are of significant interest to astrobiology from the perspective of potential life on the Red Planet. Halorubrum lacusprofundi, a cold-adapted halophilic Antarctic archaeon, was able to grow anaerobically on $0.04 \mathrm{M}$ concentration of perchlorate. With increasing concentrations of perchlorate, growth was inhibited, with half-maximal growth rate in $c a .0 .3 M \mathrm{NaClO}_{4}$ and $0.1 \mathrm{M}$ $\mathrm{Mg}\left(\mathrm{ClO}_{4}\right)_{2}$ under aerobic conditions. Magnesium ions were also inhibitory for growth, but at considerably higher concentrations, with half-maximal growth rate above $1 M$. For a purified halophilic $\beta$-galactosidase enzyme of $H$. lacusprofundi expressed in Halobacterium sp. NRC-1, 50\% inhibition of catalytic activity was observed at $0.88 \mathrm{M} \mathrm{NaClO}_{4}$ and $0.13 \mathrm{M} \mathrm{Mg}\left(\mathrm{ClO}_{4}\right)_{2}$. Magnesium ions were a more potent inhibitor of the enzyme than of cell growth. Steady-state kinetic analysis showed that $\mathrm{Mg}\left(\mathrm{ClO}_{4}\right)_{2}$ acts as a mixed inhibitor $\left(K_{\mathrm{I}}=0.04 M\right)$, with magnesium alone being a competitive inhibitor $\left(K_{\mathrm{I}}=0.3 M\right)$ and perchlorate alone acting as a very weak noncompetitive inhibitor $\left(K_{\mathrm{I}}=2 M\right)$. Based on the estimated concentrations of perchlorate salts on the surface of Mars, our results show that neither sodium nor magnesium perchlorates would significantly inhibit growth and enzyme activity of halophiles. This is the first study of perchlorate effects on a purified enzyme. Key Words: Halophilic archaea-Perchlorate-Enzyme inhibition-Magnesium. Astrobiology 18, 412-418.
\end{abstract}

\section{Introduction}

$\mathbf{H}$ ALOPHILES HAVE long been proposed as candidates for survival on Mars since they have evolved to grow in high salt concentrations and multiple extreme conditions on Earth (Landis, 2001; DasSarma, 2006). Their ability to grow in hypersaline environments requires adaptation to a number of other stressors ranging from toxic ions, periods of desiccation, and UV and ionizing radiation (Oren et al., 2014; DasSarma and DasSarma, 2017). A few halophiles, including halophilic archaea, are also adapted to cold temperatures, including subzero temperatures, with the freezing point of water depressed by high salinity (Reid et al., 2006). As a result, these extremophilic microbes may represent potential models for life on Mars where these stressors are commonly found.

Over the past 10 years, the chemical composition on the surface of Mars has been increasingly probed, both remotely and by rovers on site. The presence of oxidizers was first suspected during the NASA Viking lander missions of the 1970s (Klein, 1978). This was later confirmed by the Phoenix lander mission where perchlorate concentrations of 0.4-0.6 wt \% (3.3 $\left.\mathrm{mM} \mathrm{Mg}{ }^{2+}, 2.4 \mathrm{mM} \mathrm{ClO}_{4}^{-}\right)$were detected by the onboard Wet Chemistry Lab (Hecht et al., 2009) and confirmed by the Sample Analysis at Mars instrument on the Mars Curiosity rover (Glavin et al., 2013). Remote spectral analysis of Palikir Crater and Hale Crater showed the potential for existence of hydrated salts rather than pure water in recurring slope lineae, consistent with magnesium perchlorate. The Horowitz Crater had larger recurring slope lineae indicative of the potential for liquid water and spectra consistent with martian soil mixed with sodium perchlorate (Ojha et al., 2015).

From the perspective of possible survival on Mars, $\mathrm{Ha}$ lorubrum lacusprofundi is a halophilic archaeon of significant interest (Reid et al., 2006; DasSarma et al., 2017). This microorganism was isolated from Deep Lake, Antarctica, which is perennially cold and hypersaline (Franzmann et al.,

University of Maryland School of Medicine, Institute of Marine and Environmental Technology, Baltimore, Maryland.

(C) Victoria J. Laye and Shiladitya DasSarma, 2018; Published by Mary Ann Liebert, Inc. This Open Access article is distributed under the terms of the Creative Commons License (http://creativecommons.org/licenses/by/4.0), which permits unrestricted use, distribution, and reproduction in any medium, provided the original work is properly credited. 
1988). Halorubrum lacusprofundi, a polyextremophile, is able to survive under both low temperatures and hypersaline conditions, with measurable growth down to $-1^{\circ} \mathrm{C}$ in medium containing $3.1 \mathrm{M} \mathrm{NaCl}$ and $0.4 \mathrm{M} \mathrm{MgCl}_{2}$ (Reid et al., 2006). The genome of $H$. lacusprofundi has been completely sequenced and its derived protein sequences analyzed bioinformatically (DasSarma et al., 2013; Anderson et al., 2016). Like other halophilic archaea, H. lacusprofundi proteins are negatively supercharged, which provides both mutual repulsion and enhanced hydration for increased solubility (Karan et al., 2012; DasSarma and DasSarma, 2015). Its conserved protein sequences were found to exhibit slightly reduced negativity at the surface compared to mesophilic, halophilic proteins, and perturbation of internal residues, correlated with enhanced function at cold, hypersaline conditions (DasSarma et al., 2013).

A polyextremophilic $\beta$-galactosidase enzyme of $\mathrm{H}$. lacusprofundi was studied in detail as a model enzyme for its evolution to extreme conditions (Karan et al., 2013). The $H$. lacusprofundi protein was overexpressed in a related halophile and purified to homogeneity, and characterized for its temperature, $\mathrm{pH}$, and salt optima. Steady-state kinetic analysis was also carried out and provided insights into its biochemical properties, which are similar to other cold-adapted enzymes (Laye et al., 2017). A homology model of the enzyme was also constructed by using a related $\beta$-galactosidase enzyme from Thermus thermophilus, with structural comparisons showing that the $H$. lacusprofundi protein has much greater surface negative charges than the thermophilic protein (-65 versus -4$)$ (DasSarma et al., 2013).

To determine the effects of martian salts on $\mathrm{H}$. lacusprofundi, we subjected the microbe and its enzyme to increasing concentrations of sodium and magnesium perchlorate. Our results show that this polyextremophilic halophile and its model enzyme, while exhibiting sensitivity to these ions, retain their ability to function in their presence at high concentrations far above what is likely to be encountered on the surface of our sister planet.

\section{Materials and Methods}

\subsection{Culturing}

For aerobic growth, cultures of halophiles were shaken in the light in test tubes at $42^{\circ} \mathrm{C}$ in $\mathrm{CM}^{+}$for Halobacterium sp. NRC-1 and at $37^{\circ} \mathrm{C}$ in ATCC 1682 media for H. lacusprofundi (Berquist et al., 2007), adjusted to the desired concentration of $\mathrm{NaClO}_{4}, \mathrm{MgCl}_{2}$, and $\mathrm{Mg}\left(\mathrm{ClO}_{4}\right)_{2}$. For anaerobic growth, cultures were grown in the dark without shaking, essentially as described previously (Oren et al., 2014). OD $_{600}$ was recorded with a Spectronic 200 (ThermoFisher Scientific, Waltham, MA) test tube reader. Growth rates were calculated by using the slope of a line of regression calculated from early to mid-log phase.

\subsection{Enzyme purification}

To purify $\beta$-galactosidase, cultures of Halobacterium sp. NRC-1 (pRK42) (Karan et al., 2013) were grown to latelog phase $\left(\mathrm{OD}_{600} \sim 1.0\right)$, harvested, resuspended in binding buffer $(20 \mathrm{~m} M$ phosphate buffer, $2.0 M \mathrm{NaCl}, 10 \%$ (v/v) glycerol, $30 \mathrm{~m} M$ imidazole, $\mathrm{pH}$ 7.4), and lysed by sonication (Model 50 Sonic Dismembrator, ThermoFisher Scientific,
Waltham, MA). Cell debris was removed by centrifugation $\left(25,000 \mathrm{~g}, 4^{\circ} \mathrm{C}, 10 \mathrm{~min}\right)$ in an Eppendorf $5417 \mathrm{C}$ centrifuge, and resulting crude extract was filtered through a $0.2 \mu \mathrm{m}$ polyethersulfone filter (ThermoFisher Scientific, Waltham, MA). The proteins were purified by using Nickel HisTrap HP Columns (GE Healthcare, Chicago, IL), equilibrated, and washed with binding buffer, and eluted sequentially with $2 M$ $\mathrm{NaCl}, 100 \mathrm{~m} M$ phosphate buffer ( $\mathrm{pH}$ 7.4) supplemented with 40, 80, 100, 200, and $500 \mathrm{~m} M$ imidazole.

Column fractions were tested for activity with $o$-nitrophenyl$\beta$-D-galactopyranoside (ONPG, ThermoFisher Scientific, Waltham, MA). Active fractions were combined and protein concentration estimated by absorption at $280 \mathrm{~nm}$ with a Shimadzu UV-1601 spectrophotometer (Shimadzu Corporation, Kyoto, Japan). To confirm purity, the protein was analyzed by $10 \%$ SDS-PAGE followed by staining with Coomassie Blue (Millipore Sigma, Billerica, MA).

\subsection{Enzyme inhibition}

The inhibitory properties of $\mathrm{Mg}^{2+}$ and $\mathrm{ClO}_{4}{ }^{-}$ions on the $\beta$-galactosidase enzyme were tested through steady-state kinetics with a Shimadzu UV-1601 spectrophotometer. The assay solution containing $10 \mu \mathrm{g} / \mathrm{mL}$ enzyme was preincubated at $50^{\circ} \mathrm{C}$ followed by addition of ONPG at three different concentrations $(1,2.5$, and $5 \mathrm{~m} M)$, and absorption was recorded at $420 \mathrm{~nm} . V_{0}$, the Michaelis constant $\left(K_{\mathrm{m}}\right)$, as well as $V_{\max }$, were determined with UV Probe ver. 4.23 software (Shimadzu Corporation, Kyoto, Japan). $k_{\text {cat }}$ was calculated from given values of $K_{\mathrm{m}}$ and $V_{\max }$. After the kinetic experiments were recorded, Lineweaver-Burk plots for each concentration of the inhibitory ion were used to determine whether the inhibition was competitive or noncompetitive. $K_{\mathrm{I}}$ was determined by using Dixon plots, which use the reciprocal velocity of multiple steady-state kinetic experiments at multiple substrate and inhibitor concentrations to extrapolate the concentration of inhibitor that results in half-maximal inhibition (Yoshino and Murakami, 2009). All experiments were run in triplicate and averages used for kinetic analysis.

\section{Results}

\subsection{Effects of perchlorate salts on haloarchaeal growth}

We first sought to determine the effect of the perchlorate anion on anaerobic growth of the Antarctic cold-adapted halophile $H$. lacusprofundi, employing Halobacterium sp. NRC-1 as a control. Halorubrum lacusprofundi cultures tested in the absence of oxygen in the dark showed that the cold-adapted species is able to grow anaerobically in media supplemented with $40 \mathrm{~m} M$ perchlorate (Fig. 1). In contrast, the model mesophilic halophile, Halobacterium sp. NRC-1, was found to be incapable of anaerobic growth with perchlorate. These findings confirmed that certain haloarchaea are capable of utilizing perchlorate as a terminal electron acceptor, whereas others are not.

To determine the inhibitory effects of higher concentrations of perchlorate, growth was monitored aerobically with up to $1 M$ sodium perchlorate, and an equivalent amount of chloride ions removed to maintain unchanged salinity. Halorubrum lacusprofundi growth rate was found to steadily decline with perchlorate concentrations from 0.2 to $1 \mathrm{M}$ 


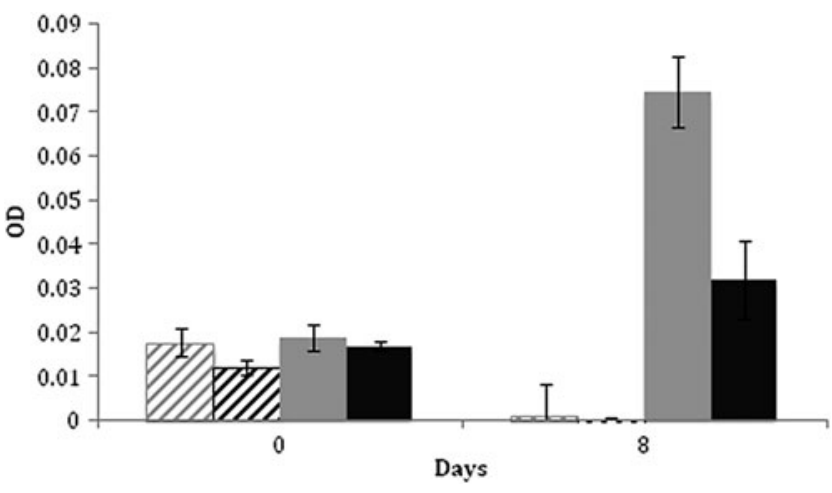

FIG. 1. Anaerobic growth assay of Halorubrum lacusprofundi and Halobacterium sp. NRC-1. Graphs show the anaerobic growth of $\mathrm{H}$. lacusprofundi (solid bars) and $\mathrm{Ha}$ lobacterium sp. NRC-1 (slashed bars) in the presence (gray) and absence (black) of $40 \mathrm{mM} \mathrm{NaClO} \mathrm{N}_{4} 0$ or 8 days after inoculation. Error bars indicate standard deviation $(n=3)$.

(Fig. 2). A $50 \%$ decrease in growth rate was observed at $0.3 \mathrm{M} \mathrm{ClO}_{4}{ }^{-}$, and complete cessation of growth occurred at $1 \mathrm{M}$. The highest concentration at which a measureable growth rate was recorded was $0.8 \mathrm{M} \mathrm{ClO}_{4}^{-}$. For Halobacterium sp. NRC-1, growth rate decreased $30 \%$ with $0.3 \mathrm{M} \mathrm{ClO}_{4}^{-}$, with a rather sudden reduction in growth rate from 0.3 to $0.4 M$ (Fig. 2). No measurable growth was observed at perchlorate concentrations of $0.4 M$ or higher.

Next, we determined the effects of magnesium perchlorate on growth rate of the two halophiles, by replacing an equivalent concentration of sodium chloride in their media, with the total anion concentration unchanged. Growth reduction by $50 \%$ was observed with $0.12 \mathrm{M} \mathrm{Mg}\left(\mathrm{ClO}_{4}\right)_{2}$ for $H$. lacusprofundi and $0.07 M$ for Halobacterium sp. NRC-1 (Fig. 2). Cessation of growth was observed with $0.3 \mathrm{M}$ $\mathrm{Mg}\left(\mathrm{ClO}_{4}\right)_{2}$ for $H$. lacusprofundi and $0.2 \mathrm{M}$ for Halobacterium sp. NRC-1. These results indicate a slightly

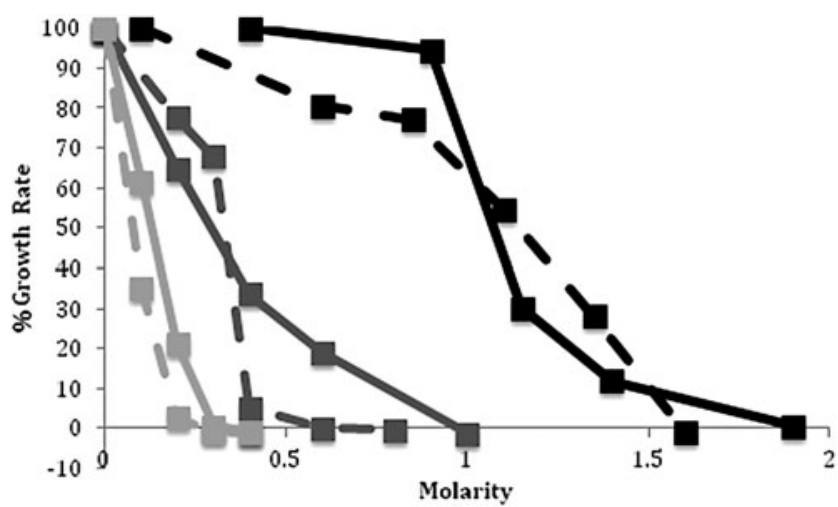

FIG. 2. Growth rates of Halorubrum lacusprofundi and Halobacterium sp. NRC-1 in the presence of added $\mathrm{MgCl}_{2}$, $\mathrm{NaClO}_{4}$, or $\mathrm{Mg}\left(\mathrm{ClO}_{4}\right)_{2}$. Graphs show the percent growth rate for Halobacterium sp. NRC-1 (dashed) and H. lacusprofundi (solid) when various concentrations of $\mathrm{MgCl}_{2}$ (black), $\mathrm{NaClO}_{4}$ (dark gray), or $\mathrm{Mg}\left(\mathrm{ClO}_{4}\right)_{2}$ (light gray) were added to $\mathrm{CM}^{+}$medium for Halobacterium sp. NRC-1 and ATCC 1682 for H. lacusprofundi. greater inhibition for the divalent cation compared to the monovalent cation at equivalent perchlorate concentration, for example, $50 \%$ inhibition with $0.12 \mathrm{M}$ magnesium perchlorate (equivalent to $0.24 M$ perchlorate ions) versus $0.3 M$ sodium perchlorate for $H$. lacusprofundi.

To discriminate the effects of magnesium cations and perchlorate anions on haloarchaeal growth, we also determined the effects of increasing cationic $\mathrm{Mg}^{2+}$ concentration on growth by addition of $\mathrm{MgCl}_{2}$ to the growth media. $\mathrm{Ha}$ lorubrum lacusprofundi retains a substantial growth rate up to $0.9 \mathrm{M} \mathrm{Mg}^{2+}$ and shows a $40 \%$ decrease in the growth rate with $1.2 \mathrm{M} \mathrm{Mg}^{2+}$ (Fig. 2). The growth rate drops $80 \%$ with $1.4 \mathrm{M} \mathrm{Mg}^{2+}$, and this is the highest concentration at which any measurable growth was observed. Halobacterium sp. NRC-1 under similar conditions also showed similar tolerance to increased $\mathrm{Mg}^{2+}$, with $50 \%$ reduction at $1.1 \mathrm{M}$ $\mathrm{MgCl}_{2}$ and complete inhibition of growth at $1.6 \mathrm{M} \mathrm{MgCl}_{2}$ (Fig. 2). These findings show that the inhibitory effect of perchlorate anions is dominant over magnesium cations for haloarchaea.

\subsection{Effects of ions on enzyme activity}

To determine the effects of magnesium perchlorate on a halophilic enzyme, we performed inhibition assays on the $H$. lacusprofundi $\beta$-galactosidase enzyme by replacing $\mathrm{NaCl}$ with either sodium or magnesium perchlorate in the reaction buffer (Fig. 3). Replacing $0.5 \mathrm{M} \mathrm{Cl}^{-}$with $\mathrm{ClO}_{4}{ }^{-}$using sodium perchlorate resulted in $30 \%$ decrease, while replacing $0.5 \mathrm{M} \mathrm{Na}^{+}$with $0.25 \mathrm{M} \mathrm{Mg}^{2+}$ using magnesium chloride resulted in $70 \%$ decrease in catalytic efficiency. With $\mathrm{Mg}\left(\mathrm{ClO}_{4}\right)_{2}$, catalytic efficiency was decreased $70 \%$ at $0.18 \mathrm{M}$, and no measurable activity was observed at $0.23 \mathrm{M}$ and higher (Fig. 3). These findings showed inhibitory effects of both ions $\mathrm{Mg}^{2+}$ and $\mathrm{ClO}_{4}^{-}$together or separately, which were significantly greater than that of reducing sodium chloride concentration alone.

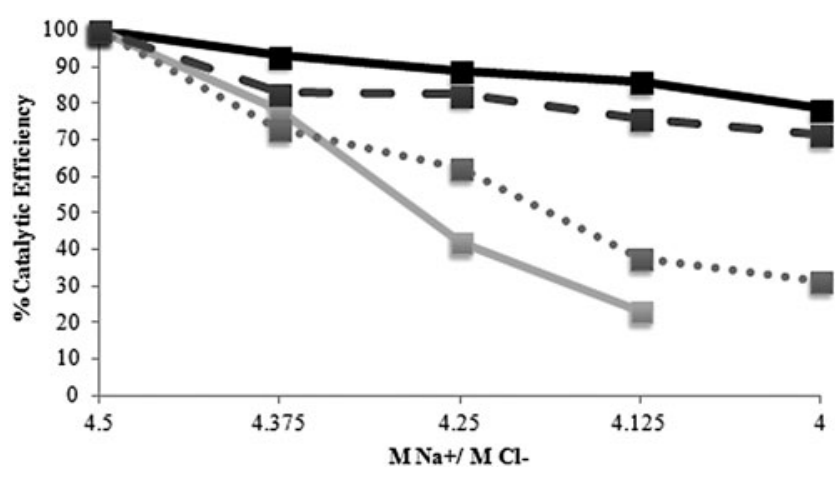

FIG. 3. Percent catalytic efficiency of $\beta$-galactosidase (pRK42) under the influence of different ions. Kinetic experiments were performed in various solutions using $10 \mu \mathrm{g} /$ $\mathrm{mL}$ of enzyme per reaction at $50^{\circ} \mathrm{C}$ with $\mathrm{ONPG}$ concentrations of $1,2.5$, and $5 \mathrm{~m} M$. Various molarities of $\mathrm{NaCl}$ were tested with no added magnesium or perchlorate (black). Ratios of sodium and magnesium chloride were tested (dotted gray). Ratios of sodium chloride and perchlorate were tested (dashed gray). Ratios of sodium chloride to magnesium perchlorate were tested (light gray). Concentrations higher than $0.18 \mathrm{M} \mathrm{Mg}\left(\mathrm{ClO}_{4}\right)_{2}$ showed no activity. 


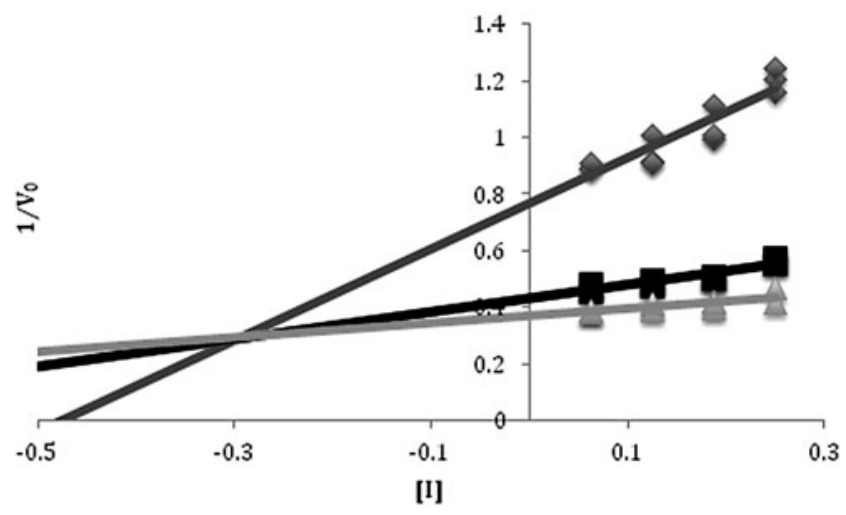

FIG. 4. Dixon plot of $\mathrm{MgCl}_{2}$ inhibition of Halorubrum lacusprofundi $\beta$-galactosidase. The inverse of $V_{0}$ for each ONPG concentration was plotted versus the concentrations of $\mathrm{MgCl}_{2}$. Where the lines intersect is the $-K_{\mathrm{I}}$. Kinetics were performed at $5 \mathrm{~m} M$ (dark gray), $2.5 \mathrm{~m} M$ (black), and $1 \mathrm{~m} M$ (light gray) ONPG in $0.0625-0.25 \mathrm{M} \mathrm{MgCl}_{2}$ and $4.375-4 \mathrm{M}$ $\mathrm{NaCl}$ at $50^{\circ} \mathrm{C}$. Each reaction had a total volume of $500 \mu \mathrm{L}$ with $10 \mu \mathrm{g} / \mathrm{mL}$ of enzyme. The value determined for $K_{\mathrm{I}}$ was $0.3 \mathrm{M}$.

To characterize the nature of inhibition, kinetic analysis was carried out for $\beta$-galactosidase reactions with added $\mathrm{MgCl}_{2}, \mathrm{NaClO}_{4}$, and $\mathrm{Mg}\left(\mathrm{ClO}_{4}\right)_{2}$. Dixon plots for magnesium chloride showed behavior as a competitive inhibitor with a $K_{\mathrm{I}}$ of $0.3 \mathrm{M}$ for $\mathrm{Mg}^{2+}$ (Fig 4). The Dixon plot for sodium perchlorate showed noncompetitive inhibition with a considerably higher $K_{\mathrm{I}}$ of $2 \mathrm{M} \mathrm{NaClO}_{4}$ (Fig 5). When the two inhibitors were combined through the addition of $\mathrm{Mg}\left(\mathrm{ClO}_{4}\right)_{2}$ to the reaction buffer, mixed inhibition characteristics were observed from the Dixon plot (Fig. 6), with a $K_{\mathrm{I}}$ of $0.04 \mathrm{M}$ for $\mathrm{Mg}\left(\mathrm{ClO}_{4}\right)_{2}$, a considerably more potent effect than when added separately.

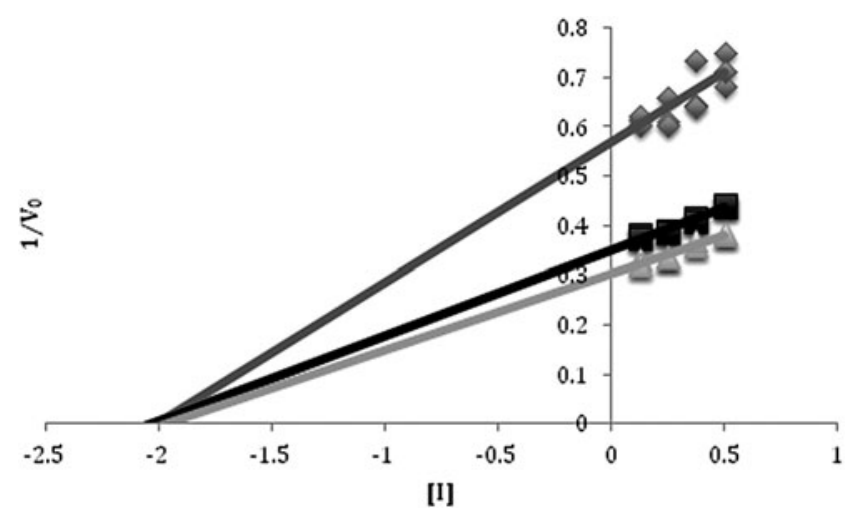

FIG. 5. Dixon plot of $\mathrm{NaClO}_{4}$ inhibition of Halorubrum lacusprofundi $\beta$-galactosidase. The inverse of $V_{0}$ for each ONPG concentration was plotted versus the concentrations of $\mathrm{NaClO}_{4}$. Where the lines intersect with each other and the $x$ axis is the $-K_{\mathrm{I}}$. Kinetics were performed at $5 \mathrm{~m} M$ (dark gray), $2.5 \mathrm{~m} M$ (black), and $1 \mathrm{~m} M$ (light gray) ONPG in $0.125-0.5 \mathrm{M} \mathrm{NaClO}_{4}$ and $4.375-4 \mathrm{M} \mathrm{NaCl}$ at $50^{\circ} \mathrm{C}$. Each reaction had a total volume of $500 \mu \mathrm{L}$ with $10 \mu \mathrm{g} / \mathrm{mL}$ of enzyme. The value determined for $K_{\mathrm{I}}$ was $2 M$.

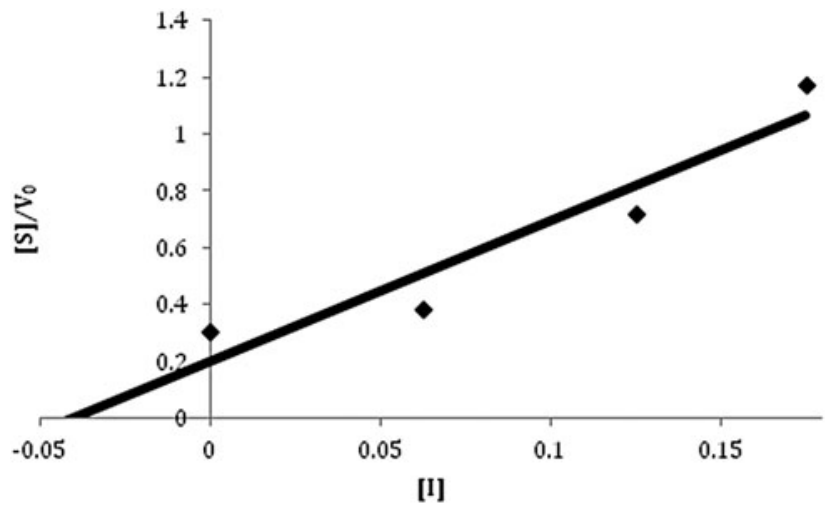

FIG. 6. Plot of $\mathrm{Mg}\left(\mathrm{ClO}_{4}\right)_{2}$ kinetics. The LineweaverBurk slope for each concentration of $\mathrm{Mg}\left(\mathrm{ClO}_{4}\right)_{2}$ was plotted against the concentration of the inhibitor using the alternative Dixon plot equation: $\frac{1}{V}=\frac{K_{m}}{V_{\max }}\left(\frac{1}{[\mathrm{~S}]}\right)\left(1+\frac{[\mathrm{I}]}{K_{I}}\right)+$ $\frac{1}{V_{\max }}\left(1+\frac{[\mathrm{I}]}{K_{I}}\right)$. A linear regression was performed, and the $x$ intercept represents the $-K_{\mathrm{I}}$. Kinetics were performed at 5 , 2.5 , and $1 \mathrm{~m} M$ ONPG in $0.0625-0.225 \mathrm{M} \mathrm{Mg}\left(\mathrm{ClO}_{4}\right)_{2}$ and $4.375-4.05 \mathrm{M} \mathrm{NaCl}$ at $50^{\circ} \mathrm{C}$. Each reaction had a total volume of $500 \mu \mathrm{L}$ with $10 \mu \mathrm{g} / \mathrm{mL}$ of enzyme. The value determined for $K_{\mathrm{I}}$ was $0.04 \mathrm{M}$.

\section{Discussion}

We investigated the effects of sodium and magnesium perchlorate salts prevalent on Mars on growth and enzyme function of a cold-adapted extreme halophile from Antarctica. Halorubrum lacusprofundi was found to grow anaerobically in low concentrations of perchlorate and was inhibited at considerably higher concentrations, with more sensitivity to magnesium perchlorate compared to sodium perchlorate $(50 \%$ inhibition at $0.3 \mathrm{M}$ sodium perchlorate versus $0.1 M$ for magnesium perchlorate). Similar results were obtained for inhibition of the purified $H$. lacusprofundi $\beta$-galactosidase enzyme, with greater enzyme activity reduction for magnesium perchlorate compared to sodium perchlorate $(50 \%$ inhibition with $0.88 \mathrm{M}$ sodium perchlorate and $0.13 M$ magnesium perchlorate). Interestingly, steadystate kinetic analysis showed that magnesium ions act as a competitive inhibitor for the enzyme, while perchlorate ions act as a noncompetitive inhibitor, with magnesium perchlorate acting as a mixed inhibitor.

According to spectroscopic analysis, martian soil contains toxic sodium and magnesium perchlorates, leading to the suggestion that Mars may not be hospitable to any form of life as we know it (Mattie et al., 2006; Wadsworth and Cockell, 2017). While there is a considerable range of concentrations of perchlorate ions on the surface of Mars, the high concentration has been estimated to be $0.1225 \mathrm{M}$ for the sodium salt and $0.0532 M$ for the magnesium salt, based on weight/volume (Ojha et al., 2015). When dissolved into soil, millimolar concentrations are expected (e.g.,

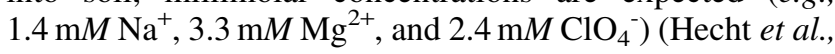
2009). These concentrations are well below the $50 \%$ inhibition rates measured for growth of both halophiles. The degree of inhibition of both growth and enzyme activity indicates that the expected concentrations of perchlorate salts on Mars would by themselves be unlikely to preclude 
success of extreme halophiles such as $H$. lacusprofundi on the Red Planet.

Compared to non-halophilic archaea, extreme halophiles may be able to tolerate higher concentrations of the perchlorate ions. For example, Methanobacterium articum M2 VKM B-2372, Methanobacterium veterum MK4 VKM B2440 , and a Methanosarcina sp. exhibited $80 \%$ reduction in methanogenesis with addition of just $9.8 \mathrm{mM} \mathrm{NaClO}_{4}$ (Shcherbakova et al., 2015), 30 times lower concentration than tolerated by $H$. lacusprofundi and Halobacterium sp. NRC-1. However, some methanogens metabolize up to $0.06 \mathrm{M} \mathrm{Mg}\left(\mathrm{ClO}_{4}\right)_{2}$ when grown on Mars soil simulant (Kral et al., 2004), with successful selection of Methanothermobacter wolfeii and Methanosarcina barkeri strains able to tolerate up to $0.3 \mathrm{M}$ perchlorate (Kral et al., 2016). These findings support the notion that halophilic and methanogenic archaea may indeed potentially survive on Mars, with growth possibly stimulated by perchlorate reduction.

Although its mechanism of action has not been extensively studied, perchlorate toxicity in microorganisms likely results from oxidative stress. Halophiles are known to be highly resistant to some of the damaging effects of oxidative stress, resulting from novel repair genes in their genomes. For example, double-stranded DNA damage repair genes that permit survival from desiccation and ionizing radiation damage have been extensively tested in the model Halobacterium sp. NRC-1 (DeVeaux et al., 2007; Karan et al., 2014). In addition, a large number of other repair systems, including novel superoxide dismutases, have been reported in the genomes of extreme halophiles (May and Dennis 1990; Joshi and Dennis 1993; Capes et al., 2011). Additional studies are required to fully understand the genetic basis of the high perchlorate tolerance in halophiles (Oosterkamp et al., 2011).

A recent report indicated that UV radiation enhances the toxicity of perchlorates in certain bacteria. When Bacillus subtilis was grown with levels of perchlorate expected on Mars, it was able to grow without any inhibition, but when those concentrations of perchlorate were combined with UV, the cells lost viability (Wadsworth and Cockell, 2017). Since halophiles display considerably more UV and perchlorate tolerance than most bacteria such as B. subtilis, the combinatorial effect may not be as debilitating (DasSarma et al., 2001; McCready et al., 2005). Halobacterium sp. NRC1 can tolerate upward of $100 \mathrm{~J} / \mathrm{m}^{2}$ of UVC radiation as a result of efficient light and dark repair systems, and may have better capability to tolerate a combination of damaging effects with perchlorate. Preliminary results indicate smaller or negligible effects with a combination of UV and perchlorate (our unpublished results).

$\mathrm{Mg}^{2+}$ ions were also inhibitory for growth of both $H$. lacusprofundi and Halobacterium sp. NRC-1, albeit less potent than perchlorate. Growth media for $H$. lacusprofundi contains $0.4 \mathrm{M}$ magnesium compared to $0.08 \mathrm{M}$ for Halobacterium sp. NRC-1, reflecting the relatively higher magnesium concentration in Deep Lake where the cold-adapted species was isolated, compared to Great Salt Lake and similar thalassic environments where the mesophile has been found. Addition of $\mathrm{Mg}^{2+}$ up to nearly $1 \mathrm{M}$ concentration did not have any significantly deleterious effect. However, at even higher concentrations, above $1 M \mathrm{Mg}^{2+}$, growth of both halophiles could be completely inhibited, with the growth rate for the cold-adapted species declining more steeply. Additional studies are needed to understand high magnesium ion tolerance and potential involvement of heavy metal efflux systems (Nies, 2003; Srivastava and Kowshik, 2013).

When looking at the effect on purified $H$. lacusprofundi $\beta$-galactosidase enzyme, $\mathrm{Mg}^{2+}$ acted as a competitive inhibitor with a $K_{\mathrm{I}}$ of $0.3 \mathrm{M}$. This $K_{\mathrm{I}}$ is lower than the concentration of $\mathrm{Mg}^{2+}$ in the medium, suggesting that, when the cation is added, it does not increase the concentration within the cell and has little effect on the enzyme function. Divalent ions have been shown to positively and negatively affect enzymatic reactions (Mordasini et al., 2003). The higher charge and smaller size of $\mathrm{Mg}^{2+}$ ions compared to sodium ions may contribute to the inhibitory effect on the enzyme through potential competition with other cation binding sites and disruption of the hydration shell. Not surprisingly, $\beta$-galactosidase is typical of halophilic proteins in having a large net surface charge and the potential of binding many positively charged $\mathrm{Mg}^{2+}$ ions (Kennedy et al., 2001). $\mathrm{Mg}^{2+}$ may also interfere with binding of zinc in $\beta$ galactosidase, although there is no known function for zinc ions in the T. thermophilus enzyme (Hidaka et al., 2002).

Perchlorate is known to be a chaotropic anion and has the potential to act as a strong denaturing agent (Zhang and Cremer, 2010). However, the anion is a noncompetitive inhibitor with a large $K_{\mathrm{I}}$ of $2 M$, indicating that it is a weak inhibitor of $\beta$-galactosidase. The denaturing and/or oxidative properties of perchlorate could explain the noncompetitive inhibitory effects on the enzyme. Perchlorate is also an effective salting-out anion, but at the concentrations tested, no protein precipitation could be observed. When compared to the weak enzyme inhibitory effect, growth of both Halobacterium sp. NRC-1 and $H$. lacusprofundi is strongly inhibited by perchlorate. This may result from facile uptake of $\mathrm{ClO}_{4}{ }^{-}$ions and other effects, for example, oxidative damage. Protein negative charges may repel the negatively charged perchlorate ions such that they may not interfere with enzyme function except at very high concentrations.

The observed effects of $\mathrm{Mg}\left(\mathrm{ClO}_{4}\right)_{2}$ suggest synergistic action of magnesium and perchlorate ions to inhibit the growth of both $H$. lacusprofundi and Halobacterium sp. NRC-1, as well as $\beta$-galactosidase enzyme activity. Both $H$. lacusprofundi and Halobacterium sp. NRC-1 exhibited $50 \%$ growth inhibition at $0.1 M \mathrm{Mg}\left(\mathrm{ClO}_{4}\right)_{2}$, which is a lower concentration than either magnesium or perchlorate ions alone. However, perchlorate has more detrimental effects on growth than magnesium ions, suggesting that halophilic cells are able to keep excess $\mathrm{Mg}^{2+}$ outside of cells, but the $\mathrm{ClO}_{4}{ }^{-}$ions are able to enter and potentially cause damage to DNA (Bauer, 2002). When looking at the purified enzyme, the main effect is competitive inhibition from the $\mathrm{Mg}^{2+}$ ions as well as the lesser effects from noncompetitive inhibition from $\mathrm{ClO}_{4}{ }^{-}$, resulting in mixed inhibition from $\mathrm{Mg}\left(\mathrm{ClO}_{4}\right)_{2}$ with a $K_{\mathrm{I}}$ of $0.04 \mathrm{M}$.

In summary, the presence of $\mathrm{Mg}\left(\mathrm{ClO}_{4}\right)_{2}$ and $\mathrm{NaClO}_{4}$ on Mars, while inhibitory for most microorganisms, likely would not preclude the growth and function of haloarchaea, such as $H$. lacusprofundi, tested in this study. Perchlorate ions do inhibit the growth of haloarchaeal cells, and magnesium ions can cause inhibition of a halophilic enzyme, but 
with complete inhibition occurring at concentrations much higher than those reported on Mars.

\section{Acknowledgments}

We thank Priya DasSarma for assistance with culturing of halophiles. This work was supported by National Aeronautics and Space Administration grant NNX15AM07G.

\section{References}

Anderson, I.J., DasSarma, P., Lucas, S., Copeland, A., Lapidus, A., Del Rio, T.G., Tice, H., Dalin, E., Bruce, D.C., Goodwin, L., Pitluck, S., Sims, D., Brettin, T.S., Detter, J.C., Han, C.S., Larimer, F., Hauser, L., Land, M., Ivanova, N., Richardson, P., Cavicchioli, R., DasSarma, S., Woese, C.R., and Kyrpides, N.C. (2016) Complete genome sequence of the Antarctic Halorubrum lacusprofundi type strain ACAM 34. Stand Genomic Sci 11, doi:10.1186/s40793-016-0194-2.

Bauer, W.R. (2002) Structure of DNA in denaturing solvents. II. Premelting unwinding of the deoxyribonucleic acid duplex by aqueous magnesium perchlorate. Biochemistry 11:29152920.

Berquist, B.R., DasSarma, P., and DasSarma, S. (2007) Essential and non-essential DNA replication genes in the model halophilic archaeon, Halobacterium sp. NRC-1. BMC Genet 8, doi:10.1186/1471-2156-8-31.

Capes, M.D., Coker, J.A., Gessler, R., Grinblat-Huse, V., DasSarma, S.L., Jacob, C.G., Kim, J.-M., DasSarma, P., and DasSarma, S. (2011) The information transfer system of halophilic archaea. Plasmid 65:77-101.

DasSarma, P., Laye, V.J., Harvey, J., Reid, C., Shultz, J., Yarborough, A., Lamb, A., Koske-Phillips, A., Herbst, A., Molina, F., Grah, O., Phillips, T., and DasSarma, S. (2017) Survival of halophilic archaea in Earth's cold stratosphere. International Journal of Astrobiology 16:321-327.

DasSarma, S. (2006) Extreme halophiles are models for astrobiology. Microbe Wash DC 1:120-126.

DasSarma, S. and DasSarma P. (2015) Halophiles and their enzymes: negativity put to good use. Curr Opin Microbiol 25: 120-126.

DasSarma, S. and DasSarma P. (2017) Halophiles. In eLS, John Wiley \& Sons, Chichester, UK, doi:10.1002/9780470015902 .a0000394.pub4.

DasSarma, S., Kennedy, S.P., Berquist, B., Ng, W.V., Baliga, N.S., Spudich, J.L., Krebs, M.P., Eisen, J.A., Johnson, C.H., and Hood, L. (2001) Genomic perspective on the photobiology of Halobacterium species NRC-1, a phototrophic, phototactic, and UV-tolerant haloarchaeon. Photosynth Res 70:3-17.

DasSarma, S., Capes, M.D., Karan, R., and DasSarma, P. (2013) Amino acid substitutions in cold-adapted proteins from $\mathrm{Ha}$ lorubrum lacusprofundi, an extremely halophilic microbe from Antarctica. PLoS One 8, doi:10.1371/journal.pone.0058587.

DeVeaux, L.C., Müller, J.A., Smith, J., Petrisko, J., Wells, D.P., and DasSarma, S. (2007) Extremely radiation-resistant mutants of a halophilic archaeon with increased single-stranded DNA-binding protein (RPA) gene expression. Radiat Res 168:507-514.

Franzmann, P., Stackebrandt, E., Sanderson, K., Volkman, J., Cameron, D., Stevenson, P., McMeekin, T., and Burton, H. (1988) Halobacterium lacusprofundi sp. nov., a halophilic bacterium isolated from Deep Lake, Antarctica. Systemat Appl Microbiol 11:20-27.
Glavin, D.P., Freissinet, C., Miller, K.E., Eigenbrode, J.L., Brunner, A.E., Buch, A., Sutter, B., Archer, P.D., Atreya, S.K., Brinckerhoff, W.B., Cabane, M., Coll, P., Conrad, P.G., Coscia, D., Dworkin, J.P., Franz, H.B., Grotzinger, J.P., Leshin, L.A., Martin, M.G., McKay, C., Ming, D.W., NavarroGonzález, R., Pavlov, A., Steele, A., Summons, R.E., Szopa, C., Teinturier, S., and Mahaffy, P.R. (2013) Evidence for perchlorates and the origin of chlorinated hydrocarbons detected by SAM at the Rocknest aeolian deposit in Gale Crater. J Geophys Res: Planets 118:1955-1973.

Hecht, M., Kounaves, S., Quinn, R., West, S., Young, S., Ming, D., Catling, D., Clark, B., Boynton, W., Hoffman, J., DeFlores, L.P., Gospodinova, K., Kapit, J., and Smith, P.H. (2009) Detection of perchlorate and the soluble chemistry of martian soil at the Phoenix lander site. Science 325: 64-67.

Hidaka, M., Fushinobu, S., Ohtsu, N., Motoshima, H., Matsuzawa, H., Shoun, H., and Wakagi, T. (2002) Trimeric crystal structure of the glycoside hydrolase family $42 \beta$-galactosidase from Thermus thermophilus A4 and the structure of its complex with galactose. J Mol Biol 322:79-91.

Joshi, P. and Dennis, P.P. (1993) Characterization of paralogous and orthologous members of the superoxide dismutase gene family from genera of the halophilic archaebacteria. $J \mathrm{Bac}$ teriol 175:1561-1571.

Karan, R., Capes, M.D., and DasSarma, S. (2012) Function and biotechnology of extremophilic enzymes in low water activity. Aquat Biosyst 8, doi:10.1186/2046-9063-8-4.

Karan, R., Capes, M.D., DasSarma, P., and DasSarma, S. (2013) Cloning, overexpression, purification, and characterization of a polyextremophilic $\beta$-galactosidase from the Antarctic haloarchaeon Halorubrum lacusprofundi. BMC Biotechnol 13, doi:10.1186/1472-6750-13-3.

Karan, R., DasSarma, P., Balcer-Kubiczek, E., Weng, R.R., Liao, C.-C., Goodlett, D.R., Ng, W.V., and DasSarma, S. (2014) Bioengineering radioresistance by overproduction of RPA, a mammalian-type single-stranded DNA-binding protein, in a halophilic archaeon. Appl Microbiol Biotechnol 98: 1737-1747.

Kennedy, S.P., Ng, W.V., Salzberg, S.L., Hood, L., and DasSarma, S. (2001) Understanding the adaptation of Halobacterium species NRC-1 to its extreme environment through computational analysis of its genome sequence. Genome Res 11:1641-1650.

Klein, H.P. (1978) The Viking biological experiments on Mars. Icarus 34:666-674.

Kral, T.A., Bekkum, C.R., and McKay, C.P. (2004) Growth of methanogens on a Mars soil simulant. Orig Life Evol Biosph 34:615-626.

Kral, T.A., Goodhart, T.H., Harpool, J.D., Hearnsberger, C.E., McCracken, G.L., and McSpadden, S.W. (2016) Sensitivity and adaptability of methanogens to perchlorates: implications for life on Mars. Planet Space Sci 120:87-95.

Landis, G.A. (2001) Martian water: are there extant halobacteria on Mars? Astrobiology 1:161-164.

Laye, V.J., Karan, R., Kim, J.-M., Pecher, W.T., DasSarma, P., and DasSarma, S. (2017) Key amino acid residues conferring enhanced enzyme activity at cold temperatures in an Antarctic polyextremophilic $\beta$-galactosidase. Proc Natl Acad Sci USA 114:12530-12535.

Mattie, D.R., Strawson, J., and Zhao, J. (2006) Perchlorate toxicity and risk assessment. In Perchlorate: Environmental Occurrence, Interactions and Treatment, edited by B. Gu and J.D. Coates, Springer, New York, pp 169-196. 
May, B.P. and Dennis, P.P. (1990) Unusual evolution of a superoxide dismutase-like gene from the extremely halophilic archaebacterium Halobacterium cutirubrum. J Bacteriol 172: 3725-3729.

McCready, S., Müller, J.A., Boubriak, I., Berquist, B.R., Ng, W.L., and DasSarma, S. (2005) UV irradiation induces homologous recombination genes in the model archaeon, Halobacterium sp. NRC-1. Saline Systems 1, doi:10.1186/ 1746-1448-1-3.

Mordasini, T., Curioni, A., and Andreoni, W. (2003) Why do divalent metal ions either promote or inhibit enzymatic reactions? The case of BamHI restriction endonuclease from combined quantum-classical simulations. J Biol Chem 278: 4381-4384.

Nies, D.H. (2003) Efflux-mediated heavy metal resistance in prokaryotes. FEMS Microbiol Rev 27:313-339.

Ojha, L., Wilhelm, M.B., Murchie, S.L., McEwen, A.S., Wray, J.J., Hanley, J., Massé, M., and Chojnacki, M. (2015) Spectral evidence for hydrated salts in recurring slope lineae on Mars. Nat Geosci 8:829-832.

Oosterkamp, M.J., Mehboob, F., Schraa, G., Plugge, C.M., and Stams, A.J. (2011) Nitrate and (per)chlorate reduction pathways in (per)chlorate-reducing bacteria. Biochem Soc Trans 39:230-235.

Oren, A., Bardavid, R.E., and Mana, L. (2014) Perchlorate and halophilic prokaryotes: implications for possible halophilic life on Mars. Extremophiles 18:75-80.

Reid, I., Sparks, W., Lubow, S., McGrath, M., Livio, M., Valenti, J., Sowers, K., Shukla, H., MacAuley, S., Miller, T., Suvanasuthi, R., Belas, R., Colman, A., Robb, F.T., DasSarma, P., Müller, J.A., Coker, J.A., Cavicchioli, R., Chen, F., and DasSarma, S. (2006) Terrestrial models for extraterrestrial life: methanogens and halophiles at martian temperatures. International Journal of Astrobiology 5:89-97.
Shcherbakova, V., Oshurkova, V., and Yoshimura, Y. (2015) The effects of perchlorates on the permafrost methanogens: implication for autotrophic life on Mars. Microorganisms 3: 518-534.

Srivastava, P. and Kowshik, M. (2013) Mechanisms of metal resistance and homeostasis in haloarchaea. Archaea 2013 doi:10.1155/2013/732864.

Wadsworth, J. and Cockell, C.S. (2017) Perchlorates on Mars enhance the bacteriocidal effects of UV light. Sci Rep 7, doi: 10.1038/s41598-017-04910-3.

Yoshino, M. and Murakami, K. (2009) A graphical method for determining inhibition constants. J Enzyme Inhib Med Chem 24, doi:10.3109/14756360902829766.

Zhang, Y. and Cremer, P.S. (2010) Chemistry of Hofmeister anions and osmolytes. Annu Rev Phys Chem 61:63-83.

Address correspondence to: Shiladitya DasSarma

University of Maryland School of Medicine Institute of Marine and Environmental Technology

University System of Maryland Columbus Center, 701 E. Pratt St. Baltimore, MD 21202

E-mail: sdassarma@som.umaryland.edu

Submitted 15 September 2017 Accepted 26 October 2017

\section{Abbreviation Used}

$\mathrm{ONPG}=o$-nitrophenyl- $\beta$-D-galactopyranoside 